\title{
Factors Influencing Success Rate of Contractors in Competitive Bidding for Construction Works in South-East, Nigeria
}

\author{
*Isaac Olaniyi Aje1, Timo Olugbenga Oladinrin² and \\ Angeline Ngozika Chibuike Nwaolel
}

Published online: 31 July 2016

To cite this article: Isaac Olaniyi Aje, Timo Olugbenga Oladinrin and Angeline Ngozika Chibuike Nwaole. (2016). Factors influencing success rate of contractors in competitive bidding for construction works in South-East, Nigeria. Journal of Construction in Developing Countries, 21 (1): 19-34. doi: 10.21315/jcdc2016.21.1.2

To link to this article: http://dx.doi.org/10.21315/jcdc2016.21.1.2

Abstract: The focal point of this study was to assess the perspectives of construction professionals on factors influencing tender prices of construction works and the contribution of the factors to the success rate of contractors. Using literature review and questionnaire survey, 15 factors were identified in respect to contractors' tender price and success rate in Nigeria. The findings of this study based on the results of statistical analyses (mean score and chi-square) reveal that all the construction professionals (architects, builders, engineers and quantity surveyors) are of the opinion that material availability, labour productivity and level of profit are the most significant factors that highly influence tender price of construction works and consequently affect the success rate of contractors in competitive bidding. Project definition and construction plan have least influence on contractors' tender price. Also, it was found that government policy does not have significant effect on contractors success rate in competitive bidding in Nigeria. It is hoped that the information presented in this paper will be of interest to all parties concerned, including Nigerian construction companies and foreign companies planning to enter the Nigerian construction market. In addition, while the research focused on a particular country, Nigeria, the study can be replicated in other countries particularly developing countries and the results can be compared.

Keywords: Contractors, Bidding, Construction, Tender, Nigeria

\section{INTRODUCTION}

The number of competitors in the construction sector is fiercely higher than most economic sectors (Enshassi, Al-Hallaq and Mohamed, 2006). As a result of this severe competition, many small and medium scale construction enterprises in the developing countries fall out of business within the first five years of establishment (Grosskopf, 2005). The Public Procurement Act 2007 of the Federal Republic of Nigeria provides that one of the condition that must be obtained before formalisation of procurement is that bids should be by open competitive bidding. The procurement has two major stages: pre-qualification and commercial stages. At the pre-qualification stage, the overall competence of prospective contractor is assessed and one of the criteria for pre-qualification of contractor is the number of projects successfully completed in the past (Ayangade, Wahab and Alake, 2009). In Nigeria, many contractors have failed in their bids to procure construction

'Department of Quantity Surveying, Federal University of Technology Akure, NIGERIA

2Department of Building and Real Estate, The Hong Kong Polytechnic University, HONG KONG

*Corresponding author: timothy.oladinrin@connect.polyu.hk 
projects and most contractors who were successful in their bid experienced cost overrun, delay and abandonment (Aibinu and Jagboro, 2002; Aibinu and Odeyinka, 2006; Ayodele and Alabi, 2011; Ibironke et al., 2013). For contractors, corporate success is central to bidding and winning contract and survival in this era of procurement of contract by "due process", which has become a new initiative being widely embraced by parties in public contract in Nigeria (Ayangade, Wahab and Alake, 2009).

The construction industry players are faced with the dilemma of bidding under competitive environment where the bid must be low enough to win the contract and high enough to attain the expected profit margin (Kimms, 2007). In coping with the situation, the contractor will normally ensure that appropriate cost estimate is determined with adequate mark up. The cost estimating function, an important element in the contractors bidding process, provides a basis for the contractor to submit a tender price for a project (Akintoye and Fitzgerald, 2000). According to Joshua (2010), a primary measure of success in preparing budget estimates is predicting the outturn capital cost and the whole life cost accurately at project inception. Without the ability to predict the outcome of a project with some degree of accuracy, it is not possible to determine which offers the best value for money. Anigbogu et al. (2007) contend that the first step toward ensuring problems are avoided in construction process is the production of accurate estimates. The consequences of bad estimate at the early stage of construction project according to Ashworth (1995) and Lowe, Emsley and Harding (2006) include embarking on an infeasible project. Contractors need to be confident that the estimates that form the basis of their tenders are realistic. If their tender prices are consistently high they will fail to attract work, alternatively if their prices are too low, they will gain work at unprofitable rates (Andrew and Baldwin, 1990). Firms generate revenue by selling their products while contractors generate revenue by winning projects. The bids may sometimes be in open competition, or invited from a prequalified list. The study by Babatunde, Opawole and Ujaddughe (2010) reveal that approximately half of construction projects in Nigeria are executed using variants of traditional method of contract procurement, in particularly, open competitive bidding and project execution at the tender sum and time are the highest factors considered for traditional method of procurement. For contractors, bidding and winning contract is central to corporate success and survival. According to Florence and Min (2005), contractors who are successful would place more emphasises on factors that affect schedule, cost and quality of the projects.

To reduce the risks associated with bidding process, it is imperative that contractors realise, understand and manage the various factors that contribute to their success rate. Thus, the main aim of this study is to assess the factors influencing success rate of contractors in competitive bidding for construction works in South-East, Nigeria with a view to reduce the rate of failure in bidding, enhance effective and efficient bidding for effective project delivery and the growth of contractors in Nigeria. It is hoped that the information presented in this paper will be of interest to all parties concerned, including Nigerian construction companies and foreign companies planning to enter the Nigerian construction market. In addition, while the research focused on a particular country, Nigeria, its findings should be applicable to other countries particularly developing countries.

20/PENERBIT UNIVERSITI SAINS MALAYSIA 


\section{THE CONCEPT OF BIDDING IN CONSTRUCTION PROCESS}

To meet specific firm objectives, bidding strategies vary from contractor to contractor and each will have different degrees of preference or sensitivity towards the factors affecting their bidding decisions. It has been found in many studies that there are differences in ranking of factors which contractors consider when making bid/no-bid and mark-up decisions: see for example, Ahmad and Minkarah (1988), Odosute and Fellows (1992), Shash (1993), Fayek, Ghoshal and AbouRizk (1999) and Oo, Drew and Runeson (2010).

There are two concepts of bidding in the construction industry: competitive and non-competitive bidding practice (Johnstone, Bedard and Ettredge, 2004). Shash (1993) argues that a construction company can either negotiate with the client or use a competitive bidding process to obtain a job. In the case of competitive bidding, openness in the process of selection becomes the underlying factor. As the name implies, it must also be competitive and transparent. This explains why it is more preferred by the public sector because as custodian of public trust, accountability and transparency becomes crucial issues in order to enhance public confidence and approval of their actions (Runeson and Skitmore, 1999). In Nigeria for instance, traditional method of construction is commonly used (Oladinrin, Olatunji and Hamza, 2013). This procurement system allows flexible application of competitive bidding in construction process.

Palaneeswaran and Kumaraswamy (2001) opine that the main implication for clients in the process of construction bidding is to obtain the most competitive bid for projects in the most efficient way. In the long run, the degree of competition must be measured in terms of capacity utilisation rather than in terms of the total level of output (Ogunsemi and Aje, 2006). It thus remains possible that the selection of contractors in competition for particular projects will not be a simple random choice that reduces the range of lowest tenders. It must be stated however that based on neo-classical micro economic theory, more tenders would not necessarily guarantee a lower price because price determination is actually based on interaction of demand and supply (Spear, 2000). Also, firms that are most desperate for jobs would also be the firms most likely to tender and thus probably the number of bidders is unlikely to have much effect on the price (Topeu, 2004). Even if it is assumed that more tenders result in a lower price and there is a direct cost of tendering, the reduction in cost for the individual project, but the increase in cost of tendering is an industry wide increase (Ofong, 1999).

Ndah (2000) states that accountability is an extremely important matter in tendering procedures and contractual arrangements so it is essential that it is considered in terms of resources used as well as the price paid. It is an important aspect of bidding in construction because it is difficult for the building owner to ascertain the quality of the final product which is mostly determined by the activities of the builder. Skitmore and $\mathrm{Ng}$ (1999) opines that competitive bidding remains the most favoured option for bid procurement in the 21 st century. Moreover, it is not easy to satisfy the building owner, that it is the lowest price when the contractor has been selected on a basis other than an equal competition with other contractors for the same project. In the public sector, civil democratic norms disapprove of disbursements of public funds in any such manner that suggests an infringement of the norms and codes of public accountability and transparency (Palaneeswaran and Kumaraswamy, 2001). Adaptation of accepted features into 
the operations format of competitive bidding procedure will definitely improve efficiency and produce better results (lyer and Jha, 2005).

It is important to note that clients' willingness to pay for construction work is influenced by their available resources as well as tender prices of other contractors. Therefore, a bidding price depends significantly on the market or competitive environment surrounding a particular construction project (Laryea and Hughes, 2010). There are two processes involved in bidding process: estimating and adjudication (Brook, 2012). While estimating deals with determination of actual project cost based on the expertise of contractor's estimating department, adjudication is concerned with determining the overall bidding price involving the decisions of company's directors. The essence of both processes is to pitch the bidding price between cost and value in order to be successful in the bidding process (Laryea and Hughes, 2008). Despite the wide acknowledgement of the factors determining contractors' success rate in previous studies, there are no studies to the best of our knowledge to review these factors in Nigeria context. Therefore, related factors were extracted from literature as summarised in Table 1 using a procedure suggested by Lu, Shen and Yam (2008) where it is recommended that relevant factors should first of all be identified prior to questionnaire survey.

Table 1. Factors Influencing Tender Prices of Construction Works

\begin{tabular}{ll}
\hline Factors & References \\
\hline Material availability & Liv et al. (2007) \\
Labour productivity & Elhag, Boussabaine and Ballal \\
(2005); Shash (1993) \\
Level of profit & Park and Chapin (1992) \\
Project financing & Han and Diekmann (2001) \\
Cost of manpower & Shash (1993) \\
Location and control of site & Akintoye (2000) \\
Zonal rates & Zou (2007) \\
Category of contractor & Shen et al. (2004) \\
Management ability & Hatush and Skitmore (1999) \\
Contract type & Drew and Skitmore (1997) \\
Method of tender selection and degree of & Oo, Drew and Lo (2008) \\
competition & \\
Government policy & Shen et al. (2004) \\
Project definition/size & Drew and Skitmore (1992) \\
Type of development & Fu, Drew and Lo (2003) \\
Construction plan & Watt, Kayis and Willey (2009) \\
\hline
\end{tabular}




\section{METHODOLOGY}

\section{Questionnaire Formulation}

The study adopted a questionnaire survey approach to achieve its aim. A thorough literature review was conducted to identify those factors that have potential influence on contractors' tender prices. As a result, 15 factors were documented in Table 1. The 15 factors were expressed in a questionnaire form for survey contained two sections. The first section was intended to collect demographic information of the respondents, the second one requested that respondents judge the importance level of the factors influencing contractors' tender prices on a predefined five-point Likert scale $(5=$ Extremely important, $4=$ Important, 3 = Neutral, 2 = Unimportant, 1 = Extremely unimportant) while the third one requested that respondents judge the significant level of the factors regarding contractors' success rate on a predefined five-point Likert scale ranging from $5=$ Highly significant to 1 = Highly insignificant

The Cronbach's alpha is a statistic that tests the reliability (the scale of the reliability coefficient) of the five-point Likert scale that was used in this study. The Cronbach's coefficient alpha that was associated with the importance of the factors influencing contractors' tender prices is 0.841 while the significant level of the factors regarding contractors' success rate is 0 . These high values indicate reliability of the questionnaire (Ameh, Soyingbe and Odusami, 2010).

\section{DATA COLLECTION}

The scope of research described in this paper is limited to construction professionals practicing within South-Eastern states of Nigeria (Abia, Anambra, Ebonyi, Enugu and Imo). This is premised on the fact that the Biafran war destroyed so many structures in this geo political zone (Nafziger, 1972) and the stable democratic government of 1999 till date has brought massive construction works being carried out in the zone. This has attracted most construction professionals and contractors to the zone which many of them have carried out many projects within and outside the zone thus making the zone an enabling environment for collection of data for the study. The sample population comprised professionals (quantity surveyors, architects, builders and engineers) who are registered members of their respective professional bodies as at December 2012 and are based in selected states. Their contact details were obtained from their various professional bodies namely Nigerian Institute of Architects (NIA), Nigerian Institute of Builders (NIOB), Nigerian Institute of Quantity Surveyors (NIQS) and Nigerian Society of Engineers (NSE) as shown in Table 2.

It is worthy to note that the questionnaires were distributed and collected personally by the researchers and some were administered through the assistance of some professional colleagues. This is due to the increased response rate identified with personal delivery and collection methods (Ki, Lee and Choi, 2012). The data collection was conducted between January 2013 and February 2014. 
Table 2. Sample Frame of Respondents

\begin{tabular}{clcccccc}
\hline S/No. & Respondent & Abia & Anambra & Ebonyi & Enugu & Imo & Total \\
\hline 1. & Architects & 25 & 27 & 17 & 68 & 37 & 174 \\
2. & Engineers & 27 & 30 & 20 & 40 & 31 & 148 \\
3. & $\begin{array}{l}\text { Professional } \\
\text { builders }\end{array}$ & 4 & 10 & 8 & 14 & 12 & 48 \\
4. & $\begin{array}{l}\text { Quantity } \\
\text { surveyors }\end{array}$ & 20 & 27 & 15 & 39 & 25 & 126 \\
\hline & Total & 76 & 94 & 60 & 161 & 105 & 496 \\
\hline
\end{tabular}

\section{Sample Size}

The sample size in respect of the various categories of respondents was determined using the following formula proposed by Yamane (1967):

$$
n=\frac{N}{1+N(e)^{2}}
$$

where, $n$ is the sample size, $N$ is the population size, and $e$ is the level of precision which is taken as $\pm 10 \%$. Substituting the pre-determined variables, the sample size for each of the study population from the different locations is as shown in Table 3. Thus, the total numbers of questionnaire administered were 379 . Out of the 379 questionnaires administered, 202 were returned by the respondents representing $53.29 \%$ of the total questionnaires sent out which is considered sufficient for the study based on the assertion of Fellows and Liu (2003) that recommend a minimum response rate of 30\% from a minimum sample size of 107 .

Table 3. Sample Size for the Category of Respondents

\begin{tabular}{clcccccc}
\hline S/No. & Respondent & Abia & Anambra & Ebonyi & Enugu & Imo & Total \\
\hline 1. & Architects & 20 & 21 & 15 & 42 & 27 & 124 \\
2. & Engineers & 21 & 23 & 17 & 29 & 24 & 114 \\
3. & $\begin{array}{l}\text { Professional } \\
\text { builders }\end{array}$ & 4 & 9 & 7 & 11 & 12 & 43 \\
4. & $\begin{array}{l}\text { Quantity } \\
\text { surveyors }\end{array}$ & 17 & 21 & 13 & 27 & 20 & 98 \\
\hline & Total & 62 & 74 & 52 & 109 & 83 & 379 \\
\hline
\end{tabular}

\section{Data Analysis and Results}

Table 4 shows the background information of the respondents who participated in the survey. It was observed that about $35 \%, 14 \%, 31 \%$ and $20 \%$ of the respondents were trained as architects, builders, engineers and quantity surveyors respectively. Considering respondents' years of working experience, $27.23 \%$ of the respondents have over 10 years of working experience, $20.79 \%$ of the respondents have above 
15 years working experience, $12.38 \%$, have above 25 years working experience in their respective firms while 14.94 have five and less years of working experience in their respective firms. Table 4 also indicates that $9.41 \%$ have handled less than five projects, $31.68 \%$ have handled over six projects and $17.82 \%$ have handled over 20 projects. The result implies that the respondents have good working experiences and are suitable for this type of research which makes the data reliable.

Table 4. Background Information of Respondents

\begin{tabular}{llcc}
\hline Category & Classification & Frequency & Percentage \\
\hline Profession of respondents & Architects & 71 & 35.15 \\
& Builders & 28 & 13.86 \\
& Engineers & 62 & 30.69 \\
& Quantity surveyors & 41 & 20.30 \\
\cline { 2 - 4 } & Total & 202 & 100.00 \\
\cline { 2 - 4 } & $0-5$ & 30 & 14.85 \\
Years of working experience of & $6-10$ & 55 & 27.23 \\
respondents & $11-15$ & 42 & 20.79 \\
& $16-20$ & 35 & 17.33 \\
& $21-25$ & 25 & 12.38 \\
Number of projects handled by & Above 25 & 15 & 7.43 \\
& $0-5$ & 19 & 9.41 \\
& $6-10$ & 64 & 31.68 \\
& $11-15$ & 24 & 11.88 \\
& $16-20$ & 34 & 16.83 \\
& $21-25$ & 36 & 17.82 \\
\hline
\end{tabular}

\section{Mean Item Score (MIS)}

Mean Item Score (MIS) was employed in assessing the perspectives of construction professionals on factors influencing tender prices of construction works. MIS was used to rank the factors based on their respective significance as used in a similar study by Lo, Fung and Tung (2006). The premise of the ranking is that the factor with the highest MIS is ranked 1st and others in such subsequent descending order. Since a five-point Likert scale will be employed for the collection of data, the formula for mean item score is written as:

$$
\text { MIS }=\frac{5 F_{5}+5 F_{4}+5 F_{3}+5 F_{2}+5 F_{1}}{F_{5}+F_{4}+F_{3}+F_{2}+F_{1}}
$$

where $F$ is the frequency of each of the rankings. 
As shown in Table 5, all the construction professionals agree that material availability, labour productivity and the level of profit are the three most important factors that influence tender prices in construction works by ranking them 1st, 2nd and 3rd respectively. The results (Table 5) equally show that all the respondents rank construction plan as the least factor that influence tender price. From the general opinion, material availability, labour productivity and level of profit are the first three factors influencing tender prices in construction works with an overall mean score ranking of $4.43,4.34$ and 4.30 respectively, closely following is the volume of profit with backup finance and level of workmanship with average mean score of 4.15 and 4.08 respectively. The least factors influencing tender prices are type of development and construction plan with an overall mean score of 3.17 and 2.94 respectively. The implication from the findings of this objective is that all the factors assessed moderately influence tender prices of construction works (Onukwube, 2002) since the overall mean score is greater than 2.5 which is the midpoint of the five-point Likert scale used in the study but some factors like material availability, labour productivity and level of profit highly influence tender prices of construction works.

Table 5. Perceptions of Construction Professionals on Factors Influencing Tender Prices of Construction Works

\begin{tabular}{|c|c|c|c|c|c|c|c|c|c|c|}
\hline \multirow{2}{*}{ Factors } & \multicolumn{2}{|c|}{ Architect } & \multicolumn{2}{|c|}{ Builders } & \multicolumn{2}{|c|}{ Engineers } & \multicolumn{2}{|c|}{ Quantity Surveyors } & \multicolumn{2}{|c|}{ Overall } \\
\hline & $\begin{array}{l}\text { Mean } \\
\text { Score }\end{array}$ & Rank & $\begin{array}{l}\text { Mean } \\
\text { Score }\end{array}$ & Rank & $\begin{array}{l}\text { Mean } \\
\text { Score }\end{array}$ & Rank & $\begin{array}{l}\text { Mean } \\
\text { Score }\end{array}$ & Rank & $\begin{array}{l}\text { Mean } \\
\text { Score }\end{array}$ & Rank \\
\hline $\begin{array}{l}\text { Material } \\
\text { availability }\end{array}$ & 4.53 & 1 & 4.63 & 1 & 4.53 & 1 & 4.7 & 1 & 4.53 & 1 \\
\hline $\begin{array}{l}\text { Labour } \\
\text { productivity }\end{array}$ & 4.39 & 2 & 4.54 & 2 & 4.44 & 2 & 4.68 & 2 & 4.34 & 2 \\
\hline Level of profit & 4.24 & 3 & 4.4 & 3 & 4.40 & 3 & 4.64 & 3 & 4.30 & 3 \\
\hline Project financing & 3.64 & 8 & 4.27 & 7 & 3.92 & 7 & 4.27 & 5 & 4.15 & 4 \\
\hline $\begin{array}{l}\text { Cost of } \\
\text { manpower }\end{array}$ & 4.12 & 4 & 4.29 & 6 & 4.25 & 4 & 4.19 & 6 & 4.08 & 5 \\
\hline $\begin{array}{l}\text { Location and } \\
\text { control of site }\end{array}$ & 3.97 & 5 & 4.35 & 4 & 4.18 & 5 & 4.10 & 7 & 4.07 & 6 \\
\hline Zonal rates & 3.93 & 6 & 4.26 & 8 & 4.17 & 6 & 4.08 & 9 & 3.82 & 7 \\
\hline $\begin{array}{l}\text { Category of } \\
\text { contractor }\end{array}$ & 3.38 & 9 & 3.70 & 10 & 3.72 & 9 & 4.41 & 4 & 3.68 & 8 \\
\hline $\begin{array}{l}\text { Management } \\
\text { ability }\end{array}$ & 3.65 & 7 & 4.28 & 5 & 3.78 & 8 & 4.09 & 8 & 3.62 & 9 \\
\hline Contract type & 3.15 & 11 & 3.38 & 13 & 3.60 & 10 & 3.90 & 13 & 3.50 & 10 \\
\hline $\begin{array}{l}\text { Method of tender } \\
\text { selection and } \\
\text { degree of } \\
\text { competition }\end{array}$ & 3.00 & 12 & 3.82 & 9 & 3.43 & 11 & 4.07 & 10 & 3.33 & 11 \\
\hline $\begin{array}{l}\text { Government } \\
\text { policy }\end{array}$ & 2.84 & 14 & 3.27 & 14 & 3.36 & 12 & 4.05 & 11 & 3.26 & 12 \\
\hline $\begin{array}{l}\text { Project } \\
\text { definition/size }\end{array}$ & 3.19 & 10 & 3.53 & 11 & 3.27 & 14 & 3.71 & 14 & 3.18 & 13 \\
\hline $\begin{array}{l}\text { Type of } \\
\text { development }\end{array}$ & 2.97 & 13 & 3.46 & 12 & 3.28 & 13 & 3.93 & 12 & 3.17 & 14 \\
\hline Construction plan & 2.80 & 15 & 3.14 & 15 & 3.04 & 15 & 3.49 & 15 & 2.94 & 15 \\
\hline
\end{tabular}

\section{Kendall's coefficient of concordance}

To determine whether there is a significant degree of agreement among the construction professionals in the factors influencing tender prices for construction works, Kendall's coefficient of concordance was used as a measure of agreement among respondents. 
Null Hypothesis, $\mathrm{H}_{\circ}$ : There is no significant agreement between the perceptions of the construction professionals on factors influencing tender prices.

Alternative Hypothesis, $\mathrm{H}_{1}$ : There is significant agreement between the perceptions of the construction professionals on the factors influencing tender prices for construction works.

The Kendall's coefficients of concordance (Wa) found equal 0.711 with $p$-value (sig.) less than the level of significance, $a=0.05$, which lead to rejection of the null hypothesis, $H_{\circ}$. Hence, there is a significant degree of agreement among the construction professionals in their perceptions of factors influencing tender prices for construction works.

\section{Chi-square test}

According Ryan (2007), chi-square $X^{2}$ statistics is a probability distribution capable of conducting tests of significance on data at nominal and ordinal levels of measurement such that conclusion can be reached whether or not the observed frequency differs significantly from expected frequency. Chi-square test was employed to test significance in nominal responses provided by respondents. The test was carried out to examine the level of significant of factors influencing tender prices on the success rate of contractors. The premise of decision is that factors influencing tender prices which $p$ value is less than 0.001 is highly significant, the factors which $p$ value is greater than 0.001 but less than 0.05 is moderately significant while factors which $p$ value is greater than 0.05 are not significant.

An aggregate analysis of all the factors influencing tenders in other of the significance to the success rate of contractors has been summarily presented in Table 6. Ranked 1st, 2nd and 3rd are material availability, labour productivity and level of profit with a mean score of $4.39,4.36$ and 4.26 respectively. Inference from Table 6 indicates that 12 out of the 15 factors are highly significant, two factors are moderately significant while one factor (government policy) with a $p$-value of 0.137 has no significant contribution to the success rate of contractors in competitive bidding of construction works.

Table 6. Significance of the Factors Determining Contractors' Success Rate in Competitive Bidding

\begin{tabular}{lccccc}
\hline Factors & Mean Score & Rank & $\begin{array}{c}\text { Chi- } \\
\text { Square } \\
\text { Value }\end{array}$ & P Value \\
\hline Material availability & 4.39 & 1 & 71.804 & $0.000^{* * *}$ \\
Labour productivity & 4.36 & 2 & 20.710 & $0.000^{* * *}$ \\
Level of profit & 4.26 & 3 & 54.607 & $0.000^{* * *}$ \\
Project financing & 4.03 & 4 & 71.551 & $0.000^{* * *}$ \\
Cost of manpower & 3.91 & 5 & 25.598 & $0.000^{* * *}$ \\
\hline & & & & (continued on next page)
\end{tabular}


Table 6. (continued)

\begin{tabular}{lcccc}
\hline Factors & Mean Score & Rank & $\begin{array}{c}\text { Chi- } \\
\text { Square } \\
\text { Value }\end{array}$ & P Value \\
\hline Location and control of site & 3.82 & 6 & 38.935 & $0.000^{* * *}$ \\
Zonal rates & 3.46 & 7 & 32.486 & $0.000^{* * *}$ \\
Category of contractor & 3.36 & 8 & 55.383 & $0.000^{* * *}$ \\
Management ability & 3.33 & 9 & 12.766 & $0.012^{* *}$ \\
Contract type & 3.12 & 10 & 53.701 & $0.000^{* * *}$ \\
Method of tender selection and degree & 2.94 & 11 & 22.206 & $0.000^{* * *}$ \\
of competition & & & & \\
Government policy & 2.85 & 12 & 6.972 & 0.137 \\
Project definition/size & 2.85 & 13 & 35.570 & $0.000^{* * *}$ \\
Type of development & 2.79 & 14 & 20.710 & $0.000^{* * *}$ \\
Construction plan & 2.67 & 15 & 9.963 & $0.041^{* *}$ \\
\hline
\end{tabular}

Notes: $* * *, * *$ significant at $\rho \leq 0.01$ and 0.05 respectively

\section{DISCUSSION}

\section{Perceptions of Construction Professionals on Factors Influencing Tender Prices of Construction Works}

The findings of this study reveal that all the construction professionals (architects, builders, engineers and quantity surveyors) are of the opinion that material availability, labour productivity and level of profit are the most significant factors that highly influence tender price of construction works. Project definition and construction plan were the least ranked with group mean scores of 3.17 and 2.94 respectively. Thus, from the professionals' perspectives, the geographic location of materials with respect to construction site location has a high significant influence on prospective tender prices as this could lead to long lead time and high cost of transportation if the distance is far. Zou, Zhang and Wang (2007) in related study on China, opine that material availability should be considered to avoid unnecessary additional cost by contractors. However, Onukwube (2002) observes that if the materials specified are available and can be locally sourced, the tender price becomes competitive.

Also, contractors should consider the rate of labour productivity during tendering process in order to avoid unnecessary delay that can warrant additional cost. Elhag, Boussabaine and Ballal (2005) examine the critical determinants of construction tendering costs in UK and found that productivity effect ranked 7th out of 18 contractor related attributes. According to Ayandele (1999), if the labour productivity of a contractor is high, it will have a positive effect on the tender prices of such a contractor. When a contractor tender an abnormally low bid without allowing for optimum profit, there is possibility of executing the job under unfavorable condition in terms of price. Although there is tendency of having high profitability level in any project which will draw potential entrants to participate in 
the project competition, giving rise to fiercer business competition and lower tender prices as advocated by Lo, Lin and Yan (2007), contractors must cautiously adopt a save profit margin. Contrary to Drew and Skitmore (1997) assertion that contract size has more influence on contractor competitiveness than contract type, it was found in this study that contract type ranked higher than project definition/size in terms of their influence on tender prices. The Kendall's coefficient of concordance (W) test reveals the views of construction professionals (architects, builders, engineers and quantity surveyors) with the value of $W=0.71$ which is greater than 0.5 , the result indicates agreement among the construction professionals in their perceptions of the factors influencing tender prices of construction works. Thus, the factors are applicable in practice as factors that influence tender price of construction works in Nigeria.

\section{Significance of Factors Influencing Tender Prices on the Success Rate of Contractors}

The results of the findings indicate that all the factors (except government policy) have significant contributions to the success rate of contractors in competitive bidding. The result of the findings is in agreement with the study by Florence and Min (2005) in Singapore which reveals that contractors who enjoy higher tendering success rate accorded a higher level of importance to factors such as project cash flow, quantum of liquidated damages, reliability of tender estimating, method of tender selection and degree of competition. Also, the finding is similar to the finding from a research conducted by Akintoye (2000) in the UK in which, material availability, project definition and level of profit were among the seven factors that influences project cost estimating price. In essence, government policy does not have any significant effect on contractors' success rate in competitive bidding in Nigeria. This may be as a result of unambiguous policies that are operative in the government system which implies that construction market in Nigeria is safe for foreign contractors. Oo, Drew and Lo (2008) suggest that contractors should apply rules of thumb that allow them to prevent pitfalls in the decision-making process and to increase their success rate.

The factors discussed in this section provide a vehicle for guiding a contractor in decision making in order to improve competitive advantage. The factors also give insights into the management of competitiveness for contractors that are operating within the context of the Nigerian construction industry so as to enhance contractor's success rate. Therefore, it is recommended that contractors should focus on the most crucial factors identified in this study (material availability, labour productivity, profit level, project financing and cost of manpower) in order to yield a maximum success rate for their respective firms and to save management efforts in considering all the relevant factors. This is due to the difficulty in satisfying all the factors at the same time as a result of limited resources (Lu, Shen and Yam, 2008).

\section{CONCLUSION}

The focal point of this study was to assess the perspectives of construction professionals on factors influencing tender prices of construction works and the 
contribution of the factors to the success rate of contractors. These factors should be considered by contractors who are willing to bid for construction works during the preparation of tender. Considering the perceptions of construction professionals on factors influencing tender prices of construction works shows that material availability, labour productivity and level of profit ranked 1st, 2nd and 3rd respectively. The least ranked factors are type of development and construction plan. Further analysis on the factors influencing tender prices to determine their significances regarding the success rate of contractors shows that 14 factors contribute significantly to the success rate of contractors in competitive bidding while government policy has no significance contribution to the success rate of contractors in competitive bidding of construction works. There is need for personal development by construction professionals involving the preparation of tender prices of construction projects especially in the areas of material availability, labour productivity and level of profit. This can be achieved by carrying out thorough market survey before pricing their tenders, assessing the level of labour productivity in the previous project and setting a reasonable profit margin.

The factors identified in this study reflect the current situation in the Nigerian construction industry in relation to competitive bidding for construction works. However, it should be recognised that the factors may change radically as Nigeria's construction industry is rapidly developing. Contractors should investigate the factors periodically to reflect the latest development of construction market and the management of competitiveness in construction bidding. It also should be noted that the factors in this study were identified from literature and assessed by focusing on the Nigerian market. Thus, the research findings may not be applicable to construction markets in other countries. Therefore, future researches should consider other factors that may be left out in this study. Also, this study can be replicated in other countries and the results can be compared. Furthermore, this study did not demonstrate in detail on how the factors can be integrated into bidding process by the contactors; future study can investigate how each of the success factors can be implemented.

\section{REFERENCES}

Ahmad, I. and Minkarah, I. (1988). Questionnaire survey on bidding in construction. Journal of Management in Engineering, 4(3): 229-243. doi: 10.1061/(ASCE)9742-597X(1988)4:3(229).

Aibinu, A.A. and Jagboro, G.O. (2002). The effects of construction delays on project delivery in Nigerian construction industry. International Journal of Project Management, 20(8): 593-599. doi: 10.1016/S0263-7863(02)00028-5.

Aibinu, A.A. and Odeyinka, H.A. (2006). Construction delays and their causative factors in Nigeria. Journal of Construction Engineering and Management, 132(7): 667-677. doi: 10.1061/(ASCE)0733-9364(2006)132:7(667).

Akintoye, A. (2000). Analysis of factors influencing project cost estimating practice. Construction Management and Economics, 18(1): 77-89. doi: 10.1080/014461900370979. 
Akintoye, A. and Fitzgerald, E. (2000). A survey of current cost estimating practice in the UK. Construction Management and Economics, 18(2): 161-172. doi: $10.1080 / 014461900370799$.

Ameh, O.J., Soyingbe, A.A. and Odusami, K.T. (2010). Significant factors causing cost overruns in telecommunication projects in Nigeria. Journal of Construction in Developing Countries, 15(2): 49-67.

Andrew, N. and Baldwin, A.T. (1990). Information technology for construction cost estimating. Habitant International, 14(2): 157-163.

Anigbogu, A.l., Achuenu, E.N., Achigbogu, A. and Kuroshi, P.A. (2007). Assembly of consultants pretender estimates of building projects in Nigeria. Journal of Construction Management and Engineering, 1 (1): 23-25.

Ashworth, A. (1995). Cost Studies of Buildings. 2nd Ed. London: Longman Group Ltd.

Ayandele, J.O. (1999). Postulates of management impact on productivity and construction of workers. The Quantity Surveyor, $29(5)$ : 19-25.

Ayangade, J.A., Wahab, A.B. and Alake, O. (2009). An Investigation of the performance of due process mechanism in the execution of construction projects in Nigeria. Civil Engineering Dimension, $11(1): 1-7$.

Ayodele, E.O. and Alabi, O.M. (2011). Abandonment of construction projects in Nigeria: Causes and effects. Journal of Emerging Trends in Economics and Management Sciences, 2(2): 142-145.

Babatunde, S.O., Opawole, A. and Ujaddughe, I.C. (2010). An appraisal of project procurement methods in the Nigeria construction industry. Civil Engineering Dimension, 12: 1-7.

Brook, M. (2012). Estimating and Tendering for Construction Work. Abingdon, UK: Routledge.

Drew, D. and Skitmore, M. (1997). The effect of contract type and size on competitiveness in bidding. Construction Management and Economic, 15(5): 469-489. doi: 10.1080/014461997372836.

Drew, D.S. and Skitmore, R.M. (1992). Competitiveness in bidding: A consultant's perspective. Construction Management and Economic, 10(3): 227-247. doi: 10.1080/01446199200000020.

Elhag, T., Boussabaine, A. and Ballal, T. (2005). Critical determinants of construction tendering costs: Quantity surveyors' standpoint. International Journal of Project Management, 23(7): 538-545. doi: 10.1016/j.jproman.2005.04.002.

Enshassi, A., Al-Hallaq, K. and Mohamed, S. (2006). Causes of contractor's business failure in developing countries: A case study of Palestine. Journal of Construction in Developing Countries, 11 (2): 1-14.

Fayek, A., Ghoshal, I. and AbouRizk, S. (1999). A survey of the bidding practices of Canadian civil engineering construction contractors. Canadian Journal of Civil Engineering, 26(1): 13-25. doi: 10.1139/198-038.

Fellows, R. and Liu, A. (2003). Data collection. In Research Methods for Construction. 2nd Ed. Oxford: Blackwell Publishing Ltd, 137-60.

Florence, Y. L. and Min, L. (2005). Factors considered by successful and profitable contractors in mark-up size decision in Singapore. Building and Environment, 40(11): 1557-1565. doi: 10.1016/j.buildenv.2004.12.001.

Fu, W.K., Drew, D.S. and Lo, H.P. (2003). Competitiveness of inexperienced and experienced contractors in bidding. Journal of Construction Engineering and Management, 129(4): 388-395. doi: 10.1061/(ASCE)07339364(2003) 129:4(388). 
Grosskopf, K.R. (2005). Teaching methods improvement using industry focus group: A case study in construction financing, construction education program. Journal of Construction Education, 1 (3): 1-25.

Han, S.H. and Diekmann, J.E. (2001). Approaches for making risk-based go/no-go decision for international projects. Journal of Construction Engineering and Management, 127(4): 300-308. doi: 10.1061/(ASCE)07339364(2001) 127:4(300).

Hatush, Z. and Skitmore, R.M. (1999). Contractor selection using multi-criteria utility theory: An additive model. Building and Environment, 33(2): 105-115.

Ibironke, O.T., Oladinrin, T.O., Adeniyi, O. and Eboreime, I.V. (2013). Analysis of nonexcusable delay factors influencing contractors' performance in Lagos State, Nigeria. Journal of Construction in Developing Countries, 18(1): 53-72.

Iyer, K.C. and Jha, K.N. (2005). Factors affecting cost performance: Evidence from Indian construction projects. International Journal of Project Management. 23(4): 283-295. doi: 10.1016/j.ijproman.2004.10.003.

Johnstone, K.M., Bedard, J.C. and Ettredge, M.L. (2004). The effect of competitive bidding on engagement planning and pricing. Contemporary Accounting Research, 21 (1): 25-53. doi: 10.1506/47TF-WHQ1-RG39-8JX4.

Joshua, O.D. (2010). Application of cost control procedures and cash flow analysis to budgetary control. Proceedings: Cost and Budget Control for National Development. University of Ibadan Conference Centre, Ibadan, Oyo State, 28 September. Oyo, Nigeria: Nigerian Institute of Quantity Surveyors.

Ki, E.J., Lee, J. and Choi, H.L. (2012). Factors affecting ethical practice of public relations professionals within public relations firms. Asian Journal of Business Ethics, 1 (2): 123-141. doi: 10.1007/s13520-011-0013-1.

Kimms, A. (2007). On the amount and timing of project payments with hints to customary contracting in Germany. Gestão \& Produção, 14(3): 441-451. doi: 10.1590/s0104-530X2007000300002.

Laryea, S. and Hughes, W. (2010). Risk and price in the bidding process of contractors. Journal of Construction Engineering and Management, 137(4): 248-258. doi: 10.1061/(ASCE)CO.1943-7862.0000293.

(2008). How contractors price risk in bids: Theory and practice. Construction Management and Economics, 26(9): 911-924. doi: 10.1080/01446190802317718.

Liu, J.Y., Li, B.G., Lin, B.S. and Nguyen, V. (2007). Key issues and challenges of risk management and insurance in China's construction industry: An empirical study. Industrial Management Data System, 107(3): 382-396. doi: $10.1108 / 02635570710734280$

Lo, T.Y., Fung, I.W. and Tung, K.C. (2006). Construction delays in Hong Kong civil engineering projects. Journal of Construction Engineering and Management, 132(6): 636-649. doi: 10.1061/(ASCE)07339364(2006) 132:6(636).

Lo, W., Lin, C. and Yan, M. (2007). Contractor's opportunistic bidding behavior and equilibrium price level in the construction market. Journal of Construction Engineering and Management, 133(6): 409-416. doi: 10.1061/(ASCE)07339364(2007)133:6(409). 
Lowe, D., Emsley, M. and Harding, A. (2006). Predicting construction cost using multiple regression techniques. Journal of Construction Engineering and Management, 132(7): 750-780. doi: 10.1061/(ASCE)07339364(2006) 132:7(750).

Lu, W., Shen, L. and Yam, M.C. (2008). Critical success factors for competitiveness of contractors: China study. Journal of Construction Engineering and Management, 134(12): 972-982. doi: 10.1061/(ASCE)07339364(2008)134:12(972).

Nafziger, E.W. (1972). The economic impact of the Nigerian Civil War. The Journal of Modern African Studies, 10(2): 223-245. doi: 10.1017/S0022278X00022369.

Ndah, T. (2000). An appraisal of types tendering arrangements: Practices, procedures and documentation. Paper presented at the Workshop on Contractual Arrangement and Contract Administration. Lagos, Nigeria, 25 July.

Odusote, O.O. and Fellows, R.F. (1992). An examination of the importance of resource considerations when contractors make project selection decisions. Construction Management and Economics, 10(2): 137-151. doi: 10.1080/01446199200000013.

Ofong, C.H.O. (1999). Open and competitive tendering: A panacea for corruption in project procurement. The Quantity Surveyor, 28(2): 21-29.

Ogunsemi, D. and Aje, I. (2006). A model for contractors' selection in Nigeria. Journal of Financial Management of Property and Construction, 11(1): 3344. doi: $10.1108 / 13664380680001078$.

Oladinrin, T.O., Olatunji, S.O. and Hamza, B.T. (2013). Effect of selected procurement systems on building project performance in Nigeria. International Journal of Sustainable Construction Engineering and Technology, 4(1): 48-62.

Onukwube, H.N. (2002). An evaluation of factors that influence tender prices of building works in Nigeria. The Quantity Surveyor, 40(3): 38-46.

Oo, B.L., Drew, D.S. and LO, H.P. (2008). A comparison of contractors' decision to bid behaviour according to different market environments. International Journal Project Management, 26(4): 439-447. doi: 10.1016/j.jproman.2007.06.001.

Oo, B.L., Drew, D.S. and Runeson, G. (2010). Competitor analysis in construction bidding. Construction Management and Economics, 28(12): 1321-1329. doi: 10.1080/01446193.2010.520721.

Palaneeswaran, E. and Kumaraswamy, C. (2001). Recent advances and proposed improvements in contractor prequalification methodologies. Building and Environment, 36(1): 73-87. doi: 10.1016/S0360-1323(99)00069-4.

Park, W.R. and Chapin, W.B. (1992). Construction Bidding: Strategic Pricing for Profit. New York: John Wiley and Sons.

Runeson, G. and Skitmore, M. (1999). Tendering theory revisited. Construction Management and Economics, 8(17): 285-296. doi: 10.1080/014461999371493.

Ryan, T.P. (2007). Modern Engineering Statistics. New Jersey: John Wiley and Sons. doi: $10.1002 / 9780470128442$.

Shash, A.A. (1993). Factors considered in tendering decisions by top UK contractors. Construction Management and Economic, 11 (2): 111-118. doi: 10.1080/01446199300000004 
Shen, L.Y., Li, Q.M., Drew, D. and Shen, Q.P. (2004). Awarding construction contracts on multicriteria basis in China. Journal of Construction Engineering and Management, 130(3): 385-393. doi: 10.1061/(ASCE)07339364(2004) 130:3(385).

Skitmore, R.M. and Ng, S.T. (1999). Client and consultant perspectives of prequalification criteria. Building and Environment, 34(5): 67-75.

Spear, J. E. (2000). The Performance Improving Contractor. Florida: Lewis Publishers.

Topeu, Y.I. (2004). A decision model proposal for construction contractor selection in Turkey. Building and Environment, 39(4): 469-481. doi: 10.1016/j.buildenv.2003.09.009.

Watt, D.J., Kayis, B. and Willey, K. (2009). Identifying key factors in the evaluation of tenders for projects and services. International Journal Project Management, 27 (3): 250-260. doi: 10.1016/j.jproman.2008.03.002.

Yamane, T. (1967). Statistics: An Introductory Analysis. 2nd Ed. New York: Harper and Row.

Zou, P.X., Zhang, G. and Wang, J. (2007). Understanding the key risks in construction projects in China. International Journal of Project Management, 25(6): 601-614. doi: 10.1016/j.jproman.2007.03.001.

Zou, P.X.W. (2007). An overview of China's construction project tendering. International Journal of Construction Management, 7(2): 23-39. doi: 10.1080/15623599.2007.10773100. 